Article

\title{
Formation of Tetranuclear Nickel(II) Complexes with Schiff-Bases: Crystal Structures and Magnetic Properties
}

\author{
Zhonglu You ${ }^{1}$, Yingying Luo ${ }^{1}$, Susan Herringer ${ }^{2}$, Yanmin Li ${ }^{1}$, Silvio Decurtins ${ }^{2}$, \\ Karl W. Krämer ${ }^{2}$ (D) and Shi-Xia Liu ${ }^{2, *(D)}$ \\ 1 Department of Chemistry and Chemical Engineering, Liaoning Normal University, Dalian 116029, China; \\ youzhonglu@innu.edu.cn (Z.Y.); ying19950819@126.com (Y.L.); liyanmin940919@126.com (Y.L.) \\ 2 Departement für Chemie und Biochemie, Universität Bern, Freiestrasse 3, CH-3012 Bern, Switzerland; \\ susan.herringer@dcb.unibe.ch (S.H.); decurtins@dcb.unibe.ch (S.D.); karl.kraemer@dcb.unibe.ch (K.W.K.) \\ * Correspondence: liu@dcb.unibe.ch; Tel.: +41-31-631-3397
}

Received: 19 June 2020; Accepted: 6 July 2020; Published: 9 July 2020

check for updates

\begin{abstract}
The cubane-type structure is a typical representative of tetranuclear coordination compounds. In this work, two anionic Schiff-base ligands, $\left(\mathrm{L}^{1}\right)^{2-}$ and $\left(\mathrm{L}^{2}\right)^{2-}$, each offering an $\mathrm{O}^{\wedge} \mathrm{N}^{\wedge} \mathrm{O}$ coordination pocket, ligate four $\mathrm{Ni}^{\mathrm{II}}$ ions into a $\left[\mathrm{Ni}_{4} \mathrm{O}_{4}\right]$ cubane core. The ligands are $\mathrm{H}_{2} \mathrm{~L}^{1}=2-[[(3-e t h o x y-2-h y d r o x y p h e n y l)$ methylene]amino]benzenemethanol and $\mathrm{H}_{2} \mathrm{~L}^{2}=2-[[(5-f l u o r o-2-h y d r o x y p h e n y l) m e t h y l e n e]$ amino]benzenemethanol. In both compounds, $\left[\mathrm{Ni}_{4}\left(\mathrm{~L}^{1}\right)_{4}(\mathrm{EtOH})_{4}\right](\mathbf{1})$ and $\left[\mathrm{Ni}_{4}\left(\mathrm{~L}^{2}\right)_{4}(\mathrm{MeOH})_{4}\right](2)$, alkoxy oxygens of the ligands act in a bridging $\mu_{3}-\mathrm{O}$ binding mode. Magnetic susceptibility and magnetization data for compounds $\mathbf{1}$ and $\mathbf{2}$ are presented. The Ni-O-Ni bond angles of the cubane core determined from single crystal X-ray diffraction data play a key role for a magneto-structural correlation. Dominant intracube ferromagnetic behavior is observed, and the coupling parameters were determined for both compounds, leading to nonzero spin ground states in accordance with the broadly accepted bond angle guideline.
\end{abstract}

Keywords: Cubane-type structure; magnetic properties; nickel cluster; Schiff-base; structure elucidation

\section{Introduction}

In the field of polynuclear coordination chemistry, skillful design strategies involving polytopic ligands often lead to predictable cluster structures, in which bridged transition metal ions exhibit appreciable magnetic spin-spin exchange [1-7]. Advantageously, such polynucleating ligands comprise coordination pockets, by which the spin centers are bound in adjacent pairs favoring intramolecular spin communication. Amongst the most versatile and widely studied ligand systems for the design of cluster compounds are polydentate Schiff-bases incorporating for the most part O/N donor atoms [8-21]. Due to the ease of access of Schiff-bases and their flexible structures, highly versatile cluster compounds with a broad variety of structure types can be realized. One prominent class of compounds shows a cubane-type structure containing four metal ions and four ligand O-donor atoms at the corners of a cube; each of the subsets forms a tetrahedron [22-30]. The compact cubane core with its specific bonding pattern allows for strong magnetic couplings between the spin centers, but also for a rich redox chemistry of the whole unit. For the latter, attention has recently been attracted for testing these tetrametallic molecular systems in applications as water oxidation catalysts [31-33] or for electrocatalytic methanol oxidation reactions [34]. In the field of molecular magnetism, cubane-like clusters have for long been in the center of magnetic studies [8-19,22-30,35-40], while deliberately and systematically looking for magnetostructural correlations. Thereby, one can note that even slight structural rearrangements of the cubane core, e.g., caused by exchange of coordinated solvent or loss 
of lattice solvent can lead to drastic changes of the magnetic properties. As a matter of facts, for $\mathrm{Ni}^{\mathrm{II}}$ cubane structures, a clear correlation between the Ni-O-Ni bond angles formed via triply-bridged oxygen atoms and the magnetic coupling strengths is observed [23,40-43]. For angles above $99^{\circ}$, the magnetic coupling between the $\mathrm{Ni}^{\mathrm{II}}$ ions is antiferromagnetic, but ferromagnetic for smaller angles. To note, structural distortions may affect this kind of guideline.

In this paper, we report the synthesis, characterization, and magnetic properties of two cubane-type complexes with stoichiometries $\left[\mathrm{Ni}_{4}\left(\mathrm{~L}^{1}\right)_{4}(\mathrm{EtOH})_{4}\right](\mathbf{1})$ and $\left[\mathrm{Ni}_{4}\left(\mathrm{~L}^{2}\right)_{4}(\mathrm{MeOH})_{4}\right](\mathbf{2})$, both based on anionic Schiff-base ligands $\left(\mathrm{L}^{1}\right)^{2-}$ and $\left(\mathrm{L}^{2}\right)^{2-}$, respectively (Figure 1$)$. The magnetic susceptibility and magnetization data were determined, and the former were fitted based on a Heisenberg Hamiltonian with two different coupling parameters $J_{1}$ and $J_{2}$ in the case of $\mathbf{1}$, and with one $J$ parameter for 2. Both compounds are found to be in a ferromagnetic coupling regime, in agreement with their structural parameters.<smiles>CCOc1cccc(/C=N/c2ccccc2CO)c1O</smiles><smiles>OCc1ccccc1/N=C/c1cc(F)ccc1O</smiles>

Figure 1. Chemical Structures of the Ligands $\mathrm{H}_{2} \mathrm{~L}^{1}$ (left) and $\mathrm{H}_{2} \mathrm{~L}^{2-}$ (right); the doubly deprotonated ligands bind to the $\mathrm{Ni}^{\mathrm{II}}$ ions of the cluster cores.

\section{Materials and Methods}

\subsection{Materials}

3-Ethoxysalicylaldehyde, 5-fluorosalicylaldehyde, and 2-aminobenzylalcohol were purchased from Sigma Aldrich, USA. Nickel acetate tetrahydrate and solvents employed for the syntheses were of analytical grade and used as received without further purification.

\subsection{General Methods}

Elemental analyses were performed on a 240C elemental analyzer (Perkin-Elmer, USA). IR spectra were recorded on an FT/IR-4000 spectrometer (Jasco, Japan) as KBr pellets in $4000-400 \mathrm{~cm}^{-1}$ region. UV-vis spectra were recorded on a Lambda 35 spectrometer (Perkin-Elmer, USA). ${ }^{1} \mathrm{H}$ and ${ }^{13} \mathrm{C}$ NMR spectra were recorded on a $500 \mathrm{MHz}$ spectrometer (Bruker, Germany). Single crystal X-ray diffraction was carried out on an Apex II CCD area diffractometer (Bruker, Germany). Powder X-ray diffraction patterns were measured on a StadiP diffractometer (STOE, Darmstadt, Germany) in Debye Scherrer geometry.

\subsection{Synthesis of Ligands and Complexes}

\subsubsection{Synthesis of $\mathrm{H}_{2} \mathrm{~L}^{1}$}

Similar to the previously reported procedure [44,45], 3-ethoxysalicylaldehyde (1.66 g, $0.01 \mathrm{~mol})$ was rected with 2-aminobenzylalcohol $(1.23 \mathrm{~g}, 0.01 \mathrm{~mol})$ in methanol $(30 \mathrm{~mL})$. The mixture was stirred at room temperature for $1 \mathrm{~h}$ to give a yellow solution, which was evaporated by distillation to give a yellow solid product. The solid was recrystallized from methanol to give the crystalline product $\mathrm{H}_{2} \mathrm{~L}^{1}$. Yield: $92 \%$. Elemental analysis (\%) calcd for $\mathrm{C}_{16} \mathrm{H}_{17} \mathrm{NO}_{3}: \mathrm{C}, 70.83 ; \mathrm{H}, 6.32 ; \mathrm{N}, 5.16$; found: $\mathrm{C}$, 70.67; H, 6.44; N, 5.0. IR data $\left(\mathrm{KBr}, \mathrm{cm}^{-1}\right): 3528(\mathrm{OH}), 1612(\mathrm{C}=\mathrm{N}), 1570,1456,1384,1245,1186,1105$, $1038,988,900,858,782,735$. UV-vis data $(\lambda, \varepsilon): 226 \mathrm{~nm}, 1.67 \times 10^{4} \mathrm{~L} \cdot \mathrm{mol}^{-1} \cdot \mathrm{cm}^{-1} ; 278 \mathrm{~nm}, 9.75 \times 10^{3}$ $\mathrm{L} \cdot \mathrm{mol}^{-1} \cdot \mathrm{cm}^{-1} ; 317 \mathrm{~nm}, 8.93 \times 10^{3} \mathrm{~L} \cdot \mathrm{mol}^{-1} \cdot \mathrm{cm}^{-1} .{ }^{1} \mathrm{H} \mathrm{NMR}\left(500 \mathrm{MHz}, d^{6}\right.$-DMSO): $\delta 13.26(\mathrm{~s}, 1 \mathrm{H}, \mathrm{OH})$, $8.87(\mathrm{~s}, 1 \mathrm{H}, \mathrm{CH}=\mathrm{N}), 7.54(\mathrm{t}, 1 \mathrm{H}, \operatorname{Ar} H), 7.36-7.31(\mathrm{~m}, 3 \mathrm{H}, \operatorname{Ar} H), 7.24(\mathrm{~d}, 1 \mathrm{H}, \operatorname{Ar} H), 7.12(\mathrm{~d}, 1 \mathrm{H}, \operatorname{Ar} H), 6.90$ 
$(\mathrm{t}, 1 \mathrm{H}, \mathrm{ArH}), 5.19(\mathrm{t}, 1 \mathrm{H}, \mathrm{OH}), 4.65\left(\mathrm{~d}, 2 \mathrm{H}, \mathrm{CH}_{2} \mathrm{OH}\right), 4.08\left(\mathrm{q}, 2 \mathrm{H}, \mathrm{OCH}_{2} \mathrm{CH}_{3}\right), 1.36\left(\mathrm{t}, 3 \mathrm{H}, \mathrm{OCH}_{2} \mathrm{CH}_{3}\right)$. ${ }^{13} \mathrm{C}$ NMR (126 MHz, DMSO) $\delta$ 163.36, 150.85, 147.03, 145.35, 135.77, 127.81, 127.37, 126.64, 124.08, $119.40,118.48,117.73,116.89,64.06,59.39,14.73$.

\subsubsection{Synthesis of $\mathrm{H}_{2} \mathrm{~L}^{2}$}

5-Fluorosalicylaldehyde ( $1.40 \mathrm{~g}, 0.01 \mathrm{~mol})$ was reacted with 2 -aminobenzylalcohol $(1.23 \mathrm{~g}, 0.01 \mathrm{~mol})$ in methanol $(30 \mathrm{~mL})$. The mixture was stirred at room temperature for $1 \mathrm{~h}$ to give a yellow solution, which was evaporated by distillation to give a yellow solid product. The solid was recrystallized from methanol to give the crystalline product $\mathrm{H}_{2} \mathrm{~L}^{2}$. Yield: $94 \%$. Elemental analysis (\%) calcd for $\mathrm{C}_{14} \mathrm{H}_{12} \mathrm{FNO}_{2}$ : C, 68.56; $\mathrm{H}, 4.93 ; \mathrm{N}, 5.71$; found: $\mathrm{C}, 68.71 ; \mathrm{H}, 5.02 ; \mathrm{N}, 5.63$. IR data $\left(\mathrm{KBr}, \mathrm{cm}^{-1}\right): 3338$ $(\mathrm{OH}), 3246,1620(\mathrm{C}=\mathrm{N}), 1565,1481,1354,1255,1197,1138,1028,957,867,778$. UV-vis data $(\lambda, \varepsilon)$ : $230 \mathrm{~nm}, 1.81 \times 10^{4} \mathrm{~L} \cdot \mathrm{mol}^{-1} \cdot \mathrm{cm}^{-1} ; 265 \mathrm{~nm}, 1.30 \times 10^{4} \mathrm{~L} \cdot \mathrm{mol}^{-1} \cdot \mathrm{cm}^{-1} ; 347 \mathrm{~nm}, 1.17 \times 10^{4} \mathrm{~L} \cdot \mathrm{mol}^{-1} \cdot \mathrm{cm}^{-1}$. ${ }^{1} \mathrm{H}$ NMR (500 MHz, d6 -DMSO): $\delta 12.70(\mathrm{~s}, 1 \mathrm{H}, \mathrm{OH}), 8.84(\mathrm{~s}, 1 \mathrm{H}, \mathrm{CH}=\mathrm{N}), 7.54$ (s, 1H, ArH), 7.38-7.28 $(\mathrm{m}, 3 \mathrm{H}, \mathrm{ArH}), 7.02(\mathrm{~m}, 2 \mathrm{H}, \mathrm{ArH}), 6.90(\mathrm{t}, 1 \mathrm{H}, \mathrm{ArH}), 5.19(\mathrm{t}, 1 \mathrm{H}, \mathrm{OH}), 4.78\left(\mathrm{~d}, 2 \mathrm{H}, \mathrm{CH}_{2} \mathrm{OH}\right) .{ }^{13} \mathrm{C}$ NMR (126 MHz, DMSO) 8 162.25, 156.96, 156.35, 151.51, 136.39, 128.37, 127.97, 120.79, 120.53, 120.24, 120.18, $118.27,115.81,59.88$.

\subsubsection{Synthesis of $\left[\mathrm{Ni}_{4}\left(\mathrm{~L}^{1}\right)_{4}(\mathrm{EtOH})_{4}\right](\mathbf{1})$}

$\mathrm{H}_{2} \mathrm{~L}^{1}(27.1 \mathrm{mg}, 0.1 \mathrm{mmol})$ was reacted with nickel acetate tetrahydrate $(24.9 \mathrm{mg}, 0.1 \mathrm{mmol})$ in ethanol $(20 \mathrm{~mL})$. The mixture was stirred at room temperature for $30 \mathrm{~min}$ to give a green solution, which was allowed to stand in air for a few days until three quarter of the solvent was evaporated. Green block-shaped single crystals of the complex were formed at the bottom of the vessel. The crystals were isolated by filtration and dried in air. Yield: $27 \%$. Elemental analysis (\%) calcd for $\mathrm{C}_{72} \mathrm{H}_{84} \mathrm{~N}_{4} \mathrm{Ni}_{4} \mathrm{O}_{16}$ : C, 57.80; H, 5.66; N, 3.74; found: C, 57.65; H, 5.72; N, 3.67. IR data $\left(\mathrm{KBr}, \mathrm{cm}^{-1}\right): 1606(\mathrm{C}=\mathrm{N}), 1541,1443,1389$, $1331,1230,1183,1108,1045,740,620,565,525,461$. UV-vis data $(\lambda, \varepsilon): 243 \mathrm{~nm}, 1.56 \times 10^{4} \mathrm{~L} \cdot \mathrm{mol}^{-1} \cdot \mathrm{cm}^{-1}$; $310 \mathrm{~nm}, 6.91 \times 10^{3} \mathrm{~L} \cdot \mathrm{mol}^{-1} \cdot \mathrm{cm}^{-1} ; 415 \mathrm{~nm}, 3.79 \times 10^{3} \mathrm{~L} \cdot \mathrm{mol}^{-1} \cdot \mathrm{cm}^{-1} ; 577 \mathrm{~nm}, 5.10 \times 10^{2} \mathrm{~L} \cdot \mathrm{mol}^{-1} \cdot \mathrm{cm}^{-1}$.

\subsubsection{Synthesis of $\left[\mathrm{Ni}_{4}\left(\mathrm{~L}^{2}\right)_{4}(\mathrm{MeOH})_{4}\right](2)$}

$\mathrm{H}_{2} \mathrm{~L}^{2}(24.5 \mathrm{mg}, 0.1 \mathrm{mmol})$ was reacted with nickel acetate tetrahydrate $(24.9 \mathrm{mg}, 0.1 \mathrm{mmol})$ in methanol $(20 \mathrm{~mL})$. The mixture was stirred at room temperature for $30 \mathrm{~min}$ to give a green solution, which was allowed to stand in air for a few days until three quarter of the solvent was evaporated. Green block-shaped single crystals of the complex were formed at the bottom of the vessel. The crystals were isolated by filtration and dried in air. Yield: $23 \%$. Elemental analysis (\%) calcd for $\mathrm{C}_{60} \mathrm{H}_{56} \mathrm{~F}_{4} \mathrm{~N}_{4} \mathrm{Ni}_{4} \mathrm{O}_{12}$ : C, 53.95; H, 4.23; N, 4.19; found: $\mathrm{C}, 54.14 ; \mathrm{H}, 4.30 ; \mathrm{N}, 4.31$. IR data $\left(\mathrm{KBr}, \mathrm{cm}^{-1}\right): 1608(\mathrm{C}=\mathrm{N}), 1538,1463$, $1386,1313,1243,1192,1135,1043,873,815,751,620,525,457$. UV-vis data $(\lambda, \varepsilon): 241 \mathrm{~nm}, 1.68 \times 10^{4}$ $\mathrm{L} \cdot \mathrm{mol}^{-1} \cdot \mathrm{cm}^{-1} ; 300 \mathrm{~nm}, 8.30 \times 10^{3} \mathrm{~L} \cdot \mathrm{mol}^{-1} \cdot \mathrm{cm}^{-1} ; 420 \mathrm{~nm}, 7.49 \times 10^{3} \mathrm{~L} \cdot \mathrm{mol}^{-1} \cdot \mathrm{cm}^{-1} ; 575 \mathrm{~nm}, 3.71 \times 10^{2}$ $\mathrm{L} \cdot \mathrm{mol}^{-1} \cdot \mathrm{cm}^{-1}$.

\subsection{X-ray Crystallography}

Diffraction intensities for the complexes were collected at 298(2) K using a Bruker Apex II CCD area-detector diffractometer with $\mathrm{MoK} \alpha$ radiation $(\lambda=0.71073 \AA)$. Collected data were reduced with SAINT [46], and multiscan absorption correction was performed using SADABS [47]. Structures of the complexes were solved by direct methods and refined against $F^{2}$ by full-matrix least-squares method using SHELXTL [48]. All nonhydrogen atoms were refined anisotropically. The hydrogen atoms were placed in calculated positions and constrained to ride on their parent atoms. The ethanol ligand C36-C35-O8 of 1 is disordered over two sites, with occupancies of $0.385(2)$ and $0.615(2)$. Crystallographic data for the complexes are summarized in Table 1. Selected Ni-L bond lengths and Ni-O-Ni angles of 1 are given in Table 2. Further L-Ni-L and Ni-O-Ni angles of $\mathbf{2}$ are reported in Supplementary Materials Table S1.

CCDC 1946462 (1) and 1946463 (2) contain the supplementary crystallographic data for this paper. These data can be obtained free of charge from the Cambridge Crystallographic Data Center, 12 Union Road, Cambridge CB2 1EZ, UK; Fax: (+44)1223-336-033; or E-mail: deposit@ccdc.cam.ac.uk. 
Table 1. Details of the data collection and refinement parameters for complexes $\mathbf{1}$ and $\mathbf{2}$.

\begin{tabular}{|c|c|c|}
\hline & 1 & 2 \\
\hline Empirical formula & $\mathrm{C}_{72} \mathrm{H}_{84} \mathrm{~N}_{4} \mathrm{Ni}_{4} \mathrm{O}_{16}$ & $\mathrm{C}_{60} \mathrm{H}_{56} \mathrm{~F}_{4} \mathrm{~N}_{4} \mathrm{Ni}_{4} \mathrm{O}_{12}$ \\
\hline Formula weight/g mol ${ }^{-1}$ & 1496.27 & 1335.93 \\
\hline Crystal shape/colour & block/green & block/green \\
\hline Crystal size/mm & $0.15 \times 0.13 \times 0.12$ & $0.11 \times 0.10 \times 0.07$ \\
\hline Crystal system & Monoclinic & Monoclinic \\
\hline Space group & $\mathrm{C} 2 / \mathrm{c}$ & $P 2_{1} / n$ \\
\hline$a(\AA)$ & 21.4621(12) & $14.8500(13)$ \\
\hline$b(\AA)$ & $14.9753(11)$ & $15.0271(11)$ \\
\hline$c(\AA)$ & $21.9416(13)$ & $27.5089(17)$ \\
\hline$\beta\left(^{\circ}\right)$ & $91.826(1)$ & $97.873(1)$ \\
\hline$V\left(\AA^{3}\right)$ & $7048.5(8)$ & $6080.8(8)$ \\
\hline Z & 4 & 4 \\
\hline$\mu(\mathrm{MoK} \alpha)\left(\mathrm{cm}^{-1}\right)$ & 1.121 & 1.295 \\
\hline$T_{\min }$ & 0.8498 & 0.8707 \\
\hline$T_{\max }$ & 0.8772 & 0.9148 \\
\hline Reflections/parameters & $20581 / 454$ & $35744 / 761$ \\
\hline Unique reflections & 6554 & 11296 \\
\hline Observed reflections $[I \geq 2 \sigma(I)]$ & 3916 & 6171 \\
\hline Restraints & 7 & 0 \\
\hline Goodness of fit on $F^{2}$ & 0.984 & 1.014 \\
\hline$R_{1}, w R_{2}[I \geq 2 \sigma(I)]$ & $0.0469,0.1027$ & $0.0658,0.1734$ \\
\hline$R_{1}, w R_{2}$ (all data) & $0.0970,0.1282$ & $0.1322,0.2174$ \\
\hline
\end{tabular}

Table 2. Selected bond lengths $(\AA)$ and angles $\left(^{\circ}\right)$ for complexes $\mathbf{1}$ and $\mathbf{2}$.

\begin{tabular}{llll}
\hline $\mathbf{1}$ & & & \\
\hline Ni1-O1 & $1.972(3)$ & Ni1-O2 & $2.002(2)$ \\
Ni1-N1 & $2.049(3)$ & Ni1-O5 & $2.092(3)$ \\
Ni1-O2' & $2.093(3)$ & Ni1-O8 & $2.171(3)$ \\
Ni2-O4 & $1.975(3)$ & Ni2-O5 & $2.003(3)$ \\
Ni2-N2 & $2.056(4)$ & Ni2-O5' & $2.095(2)$ \\
Ni2-O2' & $2.100(3)$ & Ni2-O7 & $2.143(3)$ \\
Ni1-O2-Ni1' & $101.56(10)$ & Ni1'-O5-Ni2 & $95.20(10)$ \\
Ni1-O2-Ni2 & $97.82(11)$ & Ni1'-O5-Ni2 & $97.62(11)$ \\
Ni1-O2'-Ni2' & $94.63(10)$ & Ni2-O5-Ni2' & $101.53(10)$ \\
2 & & & \\
Ni1-O1 & $1.971(5)$ & Ni1-O2 & $1.994(4)$ \\
Ni1-N1 & $2.047(6)$ & Ni1-O4 & $2.099(4)$ \\
Ni1-O6 & $2.114(4)$ & Ni1-O9 & $2.153(5)$ \\
Ni2-O3 & $1.971(4)$ & Ni2-O4 & $1.999(4)$ \\
Ni2-N2 & $2.050(5)$ & Ni2-O8 & $2.085(4)$ \\
Ni2-O2 & $2.093(4)$ & Ni2-O10 & $2.158(5)$ \\
Ni3-O5 & $1.973(5)$ & Ni3-O6 & $2.001(4)$ \\
Ni3-N3 & $2.060(6)$ & Ni3-O8 & $2.102(4)$ \\
Ni3-O4 & $2.102(4)$ & Ni3-O11 & $2.182(5)$ \\
Ni4-O7 & $1.970(4)$ & Ni4-O8 & $1.995(4)$ \\
Ni4-N4 & $2.049(5)$ & Ni4-O6 & $2.086(4)$ \\
Ni4-O2 & $2.099(4)$ & Ni4-O12 & $2.166(5)$ \\
Ni1-O2-Ni2 & $100.6(2)$ & Ni1-O2-Ni4 & $98.6(2)$ \\
Ni1-O4-Ni2 & $100.3(2)$ & Ni2-O2-Ni4 & $94.5(2)$ \\
Ni1-O4-Ni3 & $96.0(2)$ & Ni2-O4-Ni3 & $98.3(2)$ \\
Ni1-O6-Ni3 & $98.7(2)$ & Ni3-O6-Ni4 & $100.3(2)$ \\
Ni1-O6-Ni4 & $95.3(2)$ & Ni2-O8-Ni3 & $95.7(2)$ \\
Ni3-O8-Ni4 & $99.9(2)$ & Ni2-O8-Ni4 & $97.8(2)$ \\
\hline & & &
\end{tabular}




\section{Results and Discussion}

\subsection{Synthesis and Characterization}

The Schiff-bases $\mathrm{H}_{2} \mathrm{~L}^{1}$ and $\mathrm{H}_{2} \mathrm{~L}^{2}$ were readily prepared by the condensation reaction of 2-aminobenzylalcohol with 3-ethoxysalicylaldehyde and 5-fluorosalicylaldehyde, respectively, in methanol. The nickel complexes $\mathbf{1}$ and $\mathbf{2}$ were prepared by the reaction of nickel acetate tetrahydrate with $\mathrm{H}_{2} \mathrm{~L}^{1}$ in ethanol, and with $\mathrm{H}_{2} \mathrm{~L}^{2}$ in methanol, respectively. Consequently, ethanol and methanol molecules were found as terminal ligands in the coordination environment of $\mathbf{1}$ and 2, respectively (vide infra).

The infrared spectra of the complexes and the free Schiff-bases were recorded in the region $4000-400 \mathrm{~cm}^{-1}$. The intense absorption bands at $1606-1608 \mathrm{~cm}^{-1}$ in the spectra of the complexes are assigned to the imine stretching frequency of the Schiff-base ligands [49]. The shift of the bands to lower frequency, compared to the free Schiff-bases $\left(1612-1620 \mathrm{~cm}^{-1}\right)$, indicates the coordination of the imine nitrogen atom to the $\mathrm{Ni}^{\mathrm{II}}$ ion $[49,50]$. The phenolic $v_{\mathrm{Ar}-\mathrm{O}}$ in the free Schiff-bases exhibits strong bands at $1245-1255 \mathrm{~cm}^{-1}$, whereas these bands are observed in the lower frequency region at 1183-1192 $\mathrm{cm}^{-1}$ in the complexes, indicating the coordination to the nickel atoms through the phenolate oxygen atoms [51]. The Schiff-base coordination to the nickel atoms is substantiated by prominent bands appearing at low wave numbers of $450-620 \mathrm{~cm}^{-1}$, which can be attributed to $v(\mathrm{Ni}-\mathrm{N})$ and $v(\mathrm{Ni}-\mathrm{O})[52]$.

The UV-vis absorption bands observed around $415-420 \mathrm{~nm}$ can be attributed to the transition from the coordinated Schiff-base ligands to the nickel atoms (LMCT) [53]. The bands centered at 241-243 and 300-310 nm may be assigned to the intraligand $\pi-\pi^{*}$ and $n-\pi^{*}$ transitions, respectively [54]. The broad low-intensity absorption bands centered at 570-580 $\mathrm{nm}$ are typical $d$ - $d$ bands for the nickel atoms [55].

\subsection{Structural Description of the Complexes}

Compounds 1 and 2 crystallize in the monoclinic space groups $C 2 / c$ and $P 21 / n$, respectively, and their molecular structures are shown in Figure 2. Both clusters present analogous stoichiometries, namely, $\left[\mathrm{Ni}_{4}\left(\mathrm{~L}^{1}\right)_{4}(\mathrm{EtOH})_{4}\right]$ for 1 and $\left[\mathrm{Ni}_{4}\left(\mathrm{~L}^{2}\right)_{4}(\mathrm{MeOH})_{4}\right]$ for $\mathbf{2}$, and they reveal the same structural architecture and binding configuration of their ligands. Therefore, the structural description is focused on compound 1 . Its main element consists in a $\left[\mathrm{Ni}_{4} \mathrm{O}_{4}\right]$ cubane core, which resides on a crystallographic two-fold rotation axis. The $\mathrm{Ni}^{\mathrm{II}}$ ions are connected by alkoxy oxygens from four anionic Schiff-base ligands $\left(\mathrm{L}^{1}\right)^{2-}$ exhibiting four $\mu_{3}-\mathrm{O}$ binding modes. It is worth noting the bridging Ni-O-Ni angles within the cubane core, which amount to $94.6^{\circ}, 97.8^{\circ}, 101.6^{\circ}$ around $\mathrm{O} 2$ and $95.2^{\circ}, 97.6^{\circ}, 101.5^{\circ}$ around O5, respectively, for complex 1 , and amount to $94.5^{\circ}, 98.6^{\circ}, 100.6^{\circ}$ around $\mathrm{O} 2,96.0^{\circ}, 98.3^{\circ}, 100.3^{\circ}$ around $\mathrm{O} 4,95.3^{\circ}, 98.7^{\circ}, 100.3^{\circ}$ around $\mathrm{O} 6$, and $95.7^{\circ}, 99.9^{\circ}, 97.9^{\circ}$ around $\mathrm{O} 8$, respectively, for complex 2. Figure 3 illustrates the cubane core of $\mathbf{1}$ and the binding mode of the deprotonated ligand $\left(\mathrm{L}^{1}\right)^{2-} \mathrm{with}^{2}$ the $\mathrm{Ni}^{\mathrm{II}}$ ion. The ligand chelates in a nearly coplanar fashion the metal ion in an $\mathrm{O}^{\wedge} \mathrm{N}^{\wedge} \mathrm{O}$ coordination pocket. The alkoxy oxygen connects three adjacent $\mathrm{Ni}^{\mathrm{II}}$ ions in a bridging $\mu_{3}-\mathrm{O}$ binding mode, whereas the phenolate oxygen binds monodentate to a $\mathrm{Ni}^{\mathrm{II}}$ ion only. In the cluster, the metal ion resides in a slightly distorted octahedral $\mathrm{NO}_{5}$ coordination geometry, comprising oxygens from three alkoxy, one phenolate, and one ethoxy group from a ligated solvent molecule, besides one imino nitrogen. We note also that the hydroxyl hydrogen atoms of the solvent ligands form intracluster hydrogen bonds with adjacent phenolate oxygen atoms (Figure 2 and Table 3). 
Table 3. Hydrogen bond distances $(\AA)$ and bond angles $\left(^{\circ}\right)$ for complexes $\mathbf{1}$ and 2.

\begin{tabular}{|c|c|c|c|c|}
\hline$D-\mathrm{H} \cdots A$ & $d(D-\mathrm{H})$ & $d(\mathrm{H} \cdots A)$ & $d(D \cdots A)$ & Angle $(D-\mathrm{H} \cdots A)$ \\
\hline \multicolumn{5}{|l|}{1} \\
\hline 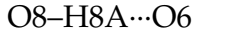 & 0.93 & 2.66 & $3.462(5)$ & $146(3)$ \\
\hline O8-H8A…O4 & 0.93 & 2.14 & $2.633(4)$ & $112(3)$ \\
\hline O7-H7A $\cdots \mathrm{O} 3$ & 0.93 & 2.64 & $3.377(5)$ & $136(3)$ \\
\hline O7-H7A $\cdots \mathrm{O} 1$ & 0.93 & 1.77 & $2.628(4)$ & $152(3)$ \\
\hline \multicolumn{5}{|l|}{2} \\
\hline $\mathrm{O} 12-\mathrm{H} 12 \cdots \mathrm{O} 3$ & 0.93 & 1.93 & $2.637(6)$ & $131(4)$ \\
\hline O11-H11A ‥O1 & 0.93 & 1.72 & $2.594(8)$ & $156(4)$ \\
\hline O10-H10‥O5 & 0.93 & 1.79 & $2.649(7)$ & $152(4)$ \\
\hline O9-H9...O7 & 0.93 & 1.90 & $2.623(7)$ & $133(4)$ \\
\hline
\end{tabular}

Symmetry code: $1-x, 2-y, 1-z$.

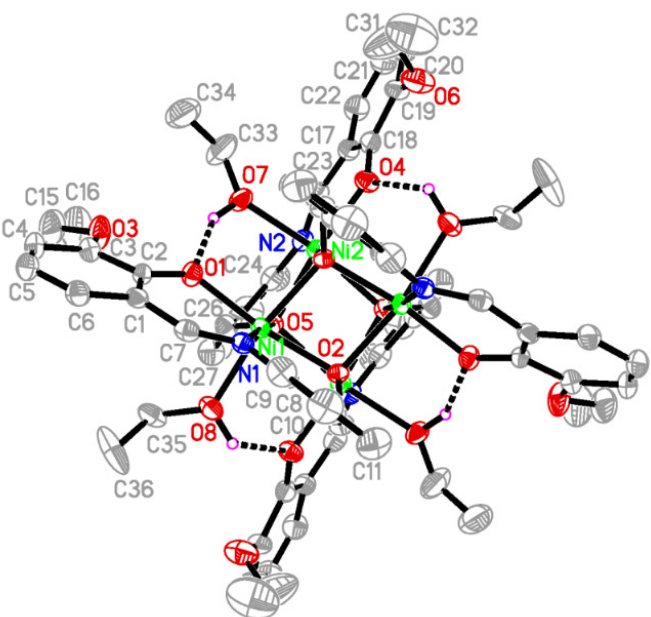

(a)

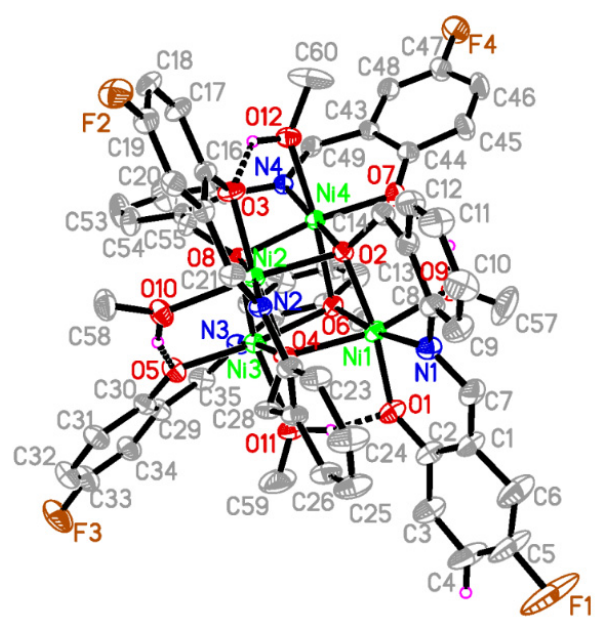

(b)

Figure 2. Crystal structures of (a) complex 1 (unlabeled atoms are related to the symmetry operation 1 $-x, y, 3 / 2-z$.) and of (b) complex 2. Hydrogen atoms except for those related to hydrogen bonds have been omitted for clarity. Intramolecular $\mathrm{O}-\mathrm{H} \cdots \mathrm{O}$ hydrogen bonds are shown as dashed lines.

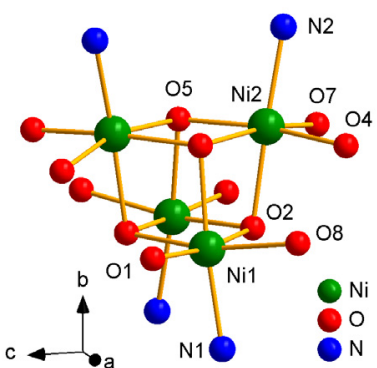

(a)

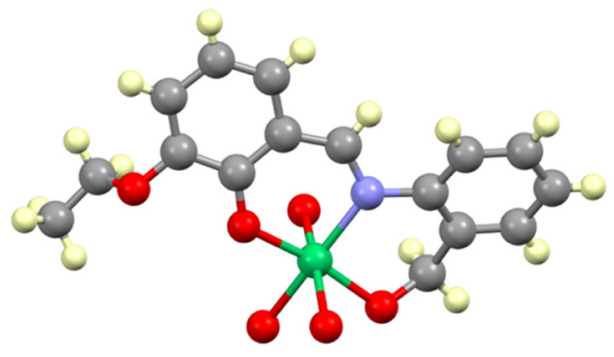

(b)

Figure 3. Cubane core (a) and fragment of structure $\mathbf{1}(\mathbf{b})$, emphasizing the binding mode of ligand $\left(\mathrm{L}^{1}\right)^{2-}$ for $\mathrm{Ni}^{\mathrm{II}}$.

In contrast to compound $\mathbf{1}$, there is no crystallographic two-fold rotation axis imposed on cluster 2, which results in an additional scant variation of the structural parameters. The binding mode of $\left(\mathrm{L}^{2}\right)^{2-}$ with the $\mathrm{Ni}^{\mathrm{II}}$ ion for 2 is shown in Supplementary Materials Figure S1. The mean bridging Ni-O-Ni angles within the cubane core of 2 taken from all four $\mu_{3}-\mathrm{O}$ atoms amount to $95.4^{\circ}, 98.3^{\circ}$, and $100.3^{\circ}$, and are thus quite similar to those for 1 . The crystal packing of both compounds shows no special 
feature, and due to the bulky ligand shell around the cubane core, the metal centers on neighbouring molecules are distant from each other $(>8.5 \AA)$, which minimizes any intercluster magnetic coupling.

In the crystal structure of $\mathbf{1}$ (Figure $4 \mathrm{a}$ ), the molecules are stacked along the $b$-axis direction. In the crystal structure of $\mathbf{2}$ (Figure $4 \mathrm{~b}$ ), two adjacent molecules are linked through intermolecular $\mathrm{C}-\mathrm{H} \cdots \mathrm{F}$ interactions, forming dimers.

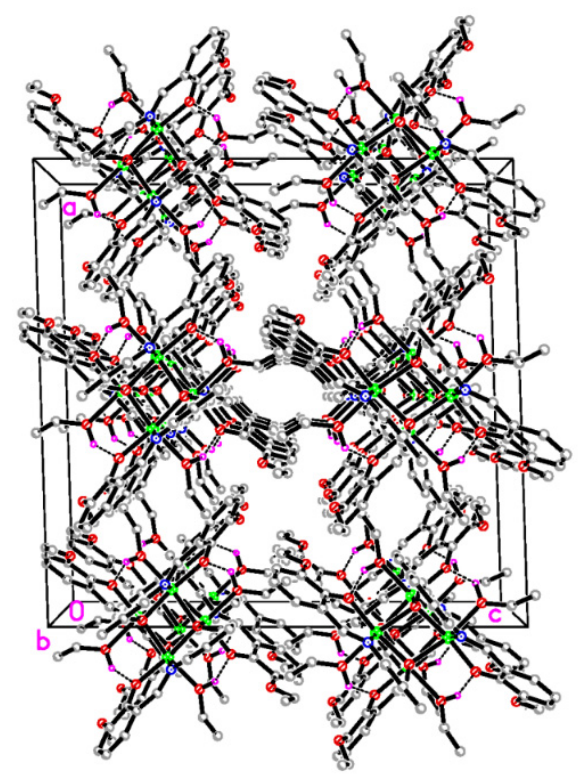

(a)

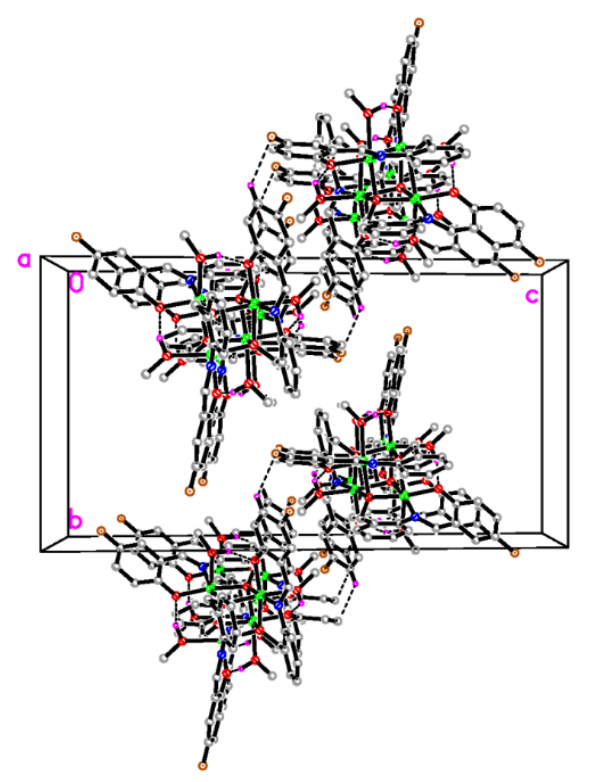

(b)

Figure 4. The molecular packing diagram of complex $\mathbf{1}$ (a, viewed along the $b$ axis) and $\mathbf{2}$ (b, viewed along the $a$ axis). Intramolecular $\mathrm{O}-\mathrm{H} \cdots \mathrm{O}$ hydrogen and intermolecular $\mathrm{C}-\mathrm{H} \cdots \mathrm{F}$ interactions are shown as dashed lines.

\subsection{Magnetic Properties}

The temperature dependence of the magnetic susceptibilities of the complexes $\mathbf{1}$ and $\mathbf{2}$ were each measured on powder samples over the temperature range $1.9-300 \mathrm{~K}$ in a 1 kOe magnetic field. Transmission powder X-ray analysis was utilized to ensure that the single-crystal data were representative of the bulk material (Supplementary Materials Figure S2). At room temperature, the $\chi_{\mathrm{M}} T$ product of 1 and 2 amounts to 5.9 and $5.8 \mathrm{~cm}^{3} \mathrm{~K} \mathrm{~mol}^{-1}$, respectively, and is thus greater than the spin-only value of $4.0 \mathrm{~cm}^{3} \mathrm{~K} \mathrm{~mol}^{-1}$ for four noninteracting $\mathrm{Ni}^{\mathrm{II}}$ ions with $S=1$ and $g=2$. Between 300 and $100 \mathrm{~K}$, the $\chi_{\mathrm{M}} T$ product for 1 and 2 increases slowly; when below $100 \mathrm{~K}$ the values increase more rapidly reaching a value of 17 and $24 \mathrm{~cm}^{3} \mathrm{~K} \mathrm{~mol}^{-1}$, respectively (Figures $5 \mathrm{a}$ and 6a). This increase in the $\chi_{\mathrm{M}} T$ product is indicative of dominant intracube ferromagnetic interactions between the paramagnetic centers. This goes in line with the $1 / \chi_{M}$ vs. $T$ plot, where the data above $200 \mathrm{~K}$ follow the Curie-Weiss law with a positive Weiss constant $\theta$ of 7.0 and $6.8 \mathrm{~K}$, respectively (Figure S3).

The field dependence of the magnetization at $1.9 \mathrm{~K}$ for $\mathbf{1}$ and $\mathbf{2}$ is shown in Figures $5 \mathrm{~b}$ and $6 \mathrm{~b}$. The magnetization shows a rapid increase up to a field of $10 \mathrm{kOe}$, after which it increases only gradually reaching at $50 \mathrm{kOe}$ values of 8.8 and $7.7 \mu_{\mathrm{B}}$, respectively. The initial steep increase of the magnetization points as well to intramolecular ferromagnetic interactions. 


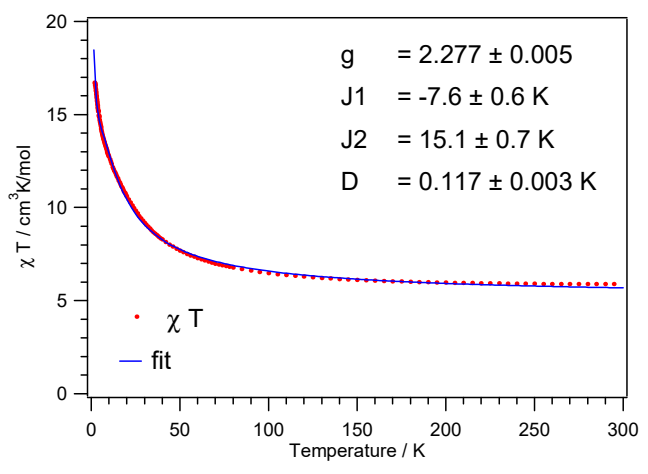

(a)

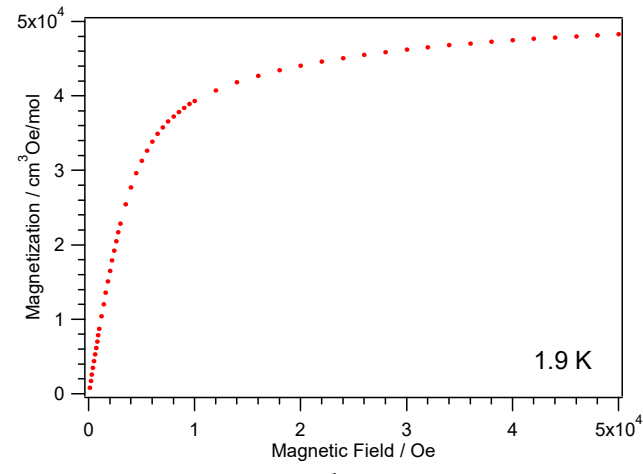

(b)

Figure 5. Temperature dependence of the $\chi_{M} T$ product (a) and magnetization vs. field (b) for $\mathbf{1}$.

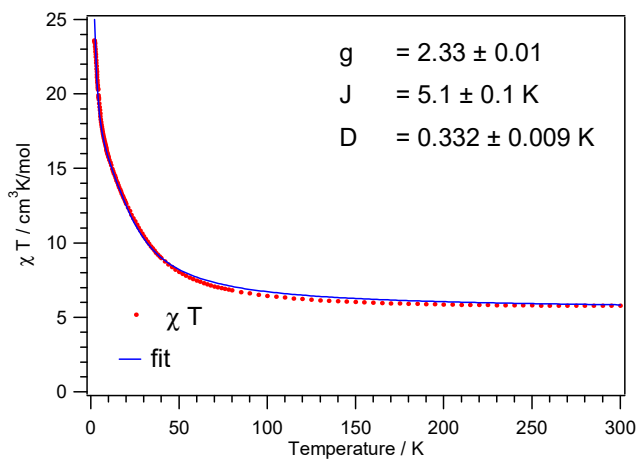

(a)

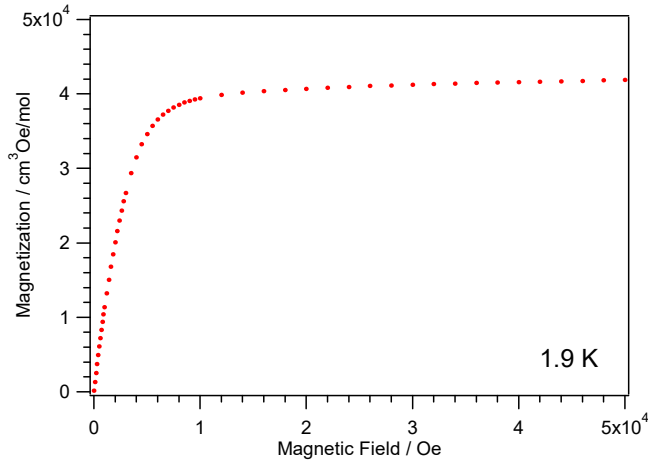

(b)

Figure 6. Temperature dependence of the $\chi_{\mathrm{M}} T$ product (a) and magnetization vs. field (b) for 2 .

Given that out of the twelve Ni-O-Ni angles per cluster, eight lie in the ferromagnetic and only four in the antiferromagnetic regime, it seems useful to apply a Heisenberg Hamiltonian containing two coupling parameters, $J_{1}$ and $J_{2}$,

$$
H=-2 J_{1}\left(S_{1} S_{2}+S_{3} S_{4}\right)-2 J_{2}\left(S_{1} S_{3}+S_{1} S_{4}+S_{2} S_{3}+S_{2} S_{4}\right)
$$

which is based on the coupling pattern as shown in Scheme 1. The Zero Field Splitting for the ground state is taken into account with the Hamiltonian

$$
H=D\left[S_{\mathrm{z}}^{2}-S(S+1) / 3\right]
$$

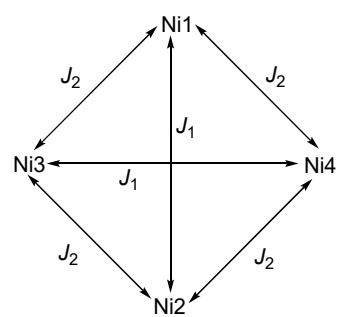

Scheme 1. Coupling scheme for 2; for 1, the cluster lies on a two-fold rotation axis and thus Ni2 is equivalent to $\mathrm{Ni} 1$ and labeled $\mathrm{Ni}^{\prime}$; correspondingly, $\mathrm{Ni} 3$ and $\mathrm{Ni} 4$ are equivalent and labeled as $\mathrm{Ni2}$, with Ni2' in the structural data, see Figure $3 b$.

This coupling scheme with the corresponding energy levels, including Van Vlecks' equation for the magnetic susceptibility and the zero field splitting Hamiltonian, has already been described 
by Escuer et al. [56]. For 1, the best fit to the $\chi_{\mathrm{M}} T$ product was achieved with parameter values for the $g$-factor $g=2.28$, the antiferromagnetic exchange parameter $J_{1}=-7.6 \mathrm{~K}$, and the ferromagnetic exchange parameter $J_{2}=15.1 \mathrm{~K}$. The resulting spin ground state, $\mathrm{S}_{\mathrm{T}}=4$, shows a small zero field splitting $D=0.12 \mathrm{~K}$, which is responsible for the continuous increase of the $\chi_{\mathrm{M}} T$ values towards lowest temperatures, see Figure 5. The fit returns well-defined values for $g$ and $D$; the parameters $J_{1}$ and $J_{2}$ are counteracting and exhibit larger error bars. The antiferromagnetic exchange $J_{1}$ is attributed to the $\mathrm{Ni1}-\mathrm{O} 2-\mathrm{Ni1}{ }^{\prime}$ and $\mathrm{Ni2}-\mathrm{O} 5-\mathrm{Ni2}{ }^{\prime}$ paths with $\mathrm{Ni}-\mathrm{O}-\mathrm{Ni}$ angles close to $101.5^{\circ}$, see Figure $3 a$ and Table 2. The ferromagnetic exchange $J_{2}$ represents an average over the remaining four paths, with $\mathrm{Ni}-\mathrm{O}-\mathrm{Ni}$ angles ranging from $94^{\circ}$ to $98^{\circ}$.

For the cubane core of 2, the $\chi_{\mathrm{M}} T$ fit results in $g=2.33, J=5.1 \mathrm{~K}$, and $D=0.33 \mathrm{~K}$, see Figure $6 \mathrm{a}$. As for 1 , the fit yields the spin ground state $\mathrm{S}_{\mathrm{T}}=4$ and returns well-defined $g$ and $D$ parameters. However, an individual fit of $J_{1}$ and $J_{2}$ parameters was impossible. These parameters are strongly correlated, and only a single average $J$ could be obtained. The cubane core of 2 exhibits no twofold rotation axis, as present in $\mathbf{1}$. The reduced symmetry of $\mathbf{2}$ results in four individual $\mathrm{Ni}^{\mathrm{II}}$ ions, see Scheme 1 , and twelve different exchange paths, see Supplementary Materials Table S1. The Ni-O-Ni angles aggregate in three groups around values of $95.4^{\circ}, 98.3^{\circ}$, and $100.3^{\circ}$, which is similar to 1 . Interestingly, a single ferromagnetic $J$ parameter well describes the data. This $J$ parameter matches well the values determined for a Ni ${ }^{\mathrm{II}}$ cubane cluster with a similar Schiff-base ligand. ${ }^{57}$ Overall, all the obtained parameters compare well with the range of parameters given in the literature for other $\mathrm{Ni}^{\mathrm{II}}$ cubane clusters [56-63].

\section{Conclusions}

In summary, two cubane-type compounds comprising a $\left[\mathrm{Ni}_{4} \mathrm{O}_{4}\right]$ core and two different chelating Schiff-base ligands that offer $\mathrm{O}^{\wedge} \mathrm{N}^{\wedge} \mathrm{O}$ coordination pockets have been synthesized and structurally as well as magnetically characterized. Both compounds show dominant intracube ferromagnetic interactions leading to a nonzero spin ground state. It has been demonstrated that even slight structural rearrangements of the cubane core due to a different substitution pattern of the ligands lead to a noticeable variation in strengths of the magnetic coupling between $\mathrm{Ni}$ (II) ions. The coupling parameters, however, correlate well with the Ni-O-Ni angles determined from single crystal structure analyses.

Supplementary Materials: The following are available online at http://www.mdpi.com/2073-4352/10/7/592/s1, Figure S1: Cubane core (left) and fragment of structure 2 (right), emphasizing the binding mode of ligand $\left(\mathrm{L}^{2}\right)^{2-}$ for $\mathrm{Ni}^{\mathrm{II}}$, Table S1: L-Ni-L angles $\left(^{\circ}\right)$ for complexes 1 and 2, Supplementary Materials Figure S2: X-ray powder diffraction pattern with simulation for 1 (top) and 2 (bottom), Figure S3: The 1/ $\chi_{M}$ vs. T plot for 1 (left) and 2 (right).

Author Contributions: Conceptualization, Z.Y.; methodology, Y.L. (Yingying Luo), S.H., and Y.L. (Yanmin Li); investigation, Y.L. (Yingying Luo), S.H., and Y.L. (Yanmin Li); writing-original draft preparation, Z.Y., K.W.K., and S.D.; writing-review and editing, S.-X.L. and S.D.; supervision, Z.Y., K.W.K., and S.D.; project administration, Z.Y. and K.W.K. All authors have read and agreed to the published version of the manuscript.

Funding: We are grateful to the Swiss National Science Foundation for financial support under project no. 200020_172659 and the State Key Laboratory of Catalysis of China (Project No. N-19-02).

Conflicts of Interest: The authors declare no conflict of interest.

\section{References}

1. Chaudhuri, P.; Kataev, V.; Büchner, B.; Klauss, H.-H.; Kersting, B.; Meyer, F. Tetranuclear complexes in molecular magnetism: Targeted synthesis, high-field EPR and pulsed-field magnetization. Coord. Chem. Rev. 2009, 253, 2261-2285. [CrossRef]

2. Thompson, L.K. Polynuclear coordination complexes-From dinuclear to nonanuclear and beyond. Coord. Chem. Rev. 2002, 233-234, 193-206. [CrossRef]

3. Fielden, J.; Speldrich, M.; Besson, C.; Kögerler, P. Chiral hexanuclear ferric wheels. Inorg. Chem. 2012, 51, 2734-2736. [CrossRef] [PubMed] 
4. Bhatt, V.; Ram, S. The role of ligands, polytopic ligands and Metal Organic Ligands (Mols) in coordination chemistry. Chem. Sci. Rev. Lett. 2015, 4, 414-428.

5. Bonanno, M.N.; Lough, J.A.; Poddutoori, K.P.; Lemaire, T.M. Synthesis, characterization and Copper(2+) coordination chemistry of a polytopic paramagnetic ligand. Magnetochemistry 2017, 3, 15. [CrossRef]

6. Winpenny, R.E.P. Molecular Cluster Magnets; World Scientific: London, UK, 2012.

7. Gatteschi, D. Molecular Nanomagnets; Oxford University Press: Oxford, UK, 2006.

8. Liu, X.; Hamon, J.-R. Recent developments in penta-, hexa- and heptadentate Schiff base ligands and their metal complexes. Coord. Chem. Rev. 2019, 389, 94-118. [CrossRef]

9. Clarke, R.M.; Herasymchuk, K.; Storr, T. Electronic structure elucidation in oxidized metal-salen complexes. Coord. Chem. Rev. 2017, 352, 67-82. [CrossRef]

10. Golcu, A.; Tumer, M.; Demirelli, H.; Wheatley, R.A. Cd(II) and Cu(II) complexes of polydentate Schiff base ligands: Synthesis, characterization, properties and biological activity. Inorg. Chim. Acta 2005, 358, 1785-1797. [CrossRef]

11. Mondal, K.C.; Kostakis, G.E.; Lan, Y.; Wernsdorfer, W.; Anson, C.E.; Powell, A.K. Defect-dicubane $\mathrm{Ni}_{2} \operatorname{Ln}_{2}$ $(\mathrm{Ln}=\mathrm{Dy}, \mathrm{Tb})$ single molecule magnets. Inorg. Chem. 2011, 50, 11604-11611. [CrossRef]

12. Kühne, I.A.; Griffiths, K.; Hutchings, A.-J.; Townrow, O.P.E.; Eichhöfer, A.; Anson, C.E.; Kostakis, G.E.; Powell, A.K. Stepwise investigation of the influences of steric groups versus counterions to target $\mathrm{Cu} / \mathrm{Dy}$ complexes. Cryst. Growth Des. 2017, 17, 5178-5190. [CrossRef]

13. Gheorghe, R.; Andreea Ionita, G.; Maxim, C.; Caneschi, A.; Sorace, L.; Andruh, M. Aggregation of heptanuclear $\left[\mathrm{M}_{7}^{\mathrm{II}}\right](\mathrm{M}=\mathrm{Co}, \mathrm{Ni}, \mathrm{Zn})$ clusters by a Schiff-base ligand derived from o-vanillin: Synthesis, crystal structures and magnetic properties. Polyhedron 2019, 171, 269-278. [CrossRef]

14. Wu, J.-C.; Liu, S.-X.; Keene, T.D.; Neels, A.; Mereacre, V.; Powell, A.K.; Decurtins, S. Coordination chemistry of a $\pi$-extended, rigid and redox-active tetrathiafulvalene-fused Schiff-base ligand. Inorg. Chem. 2008, 47, 3452-3459. [CrossRef] [PubMed]

15. Opstal, T.; Verpoort, F. Synthesis of highly active ruthenium indenylidene complexes for atom-transfer radical polymerization and ring-opening-metathesis polymerization. Angew. Chem. Int. Ed. 2003, 42, 2876-2879. [CrossRef] [PubMed]

16. De Clercq, B.; Verpoort, F. Atom transfer radical polymerization of vinyl monomers mediated by Schiff base ruthenium-alkylidene catalysts and the adventitious effect of water in polymerizations with the analogous cationic complexes. Macromolecules 2002, 35, 8943-8947. [CrossRef]

17. Hazra, S.; Koner, R.; Lemoine, P.; Sañudo, E.C.; Mohanta, S. Syntheses, structures and magnetic properties of heterobridged dinuclear and cubane-type tetranuclear complexes of Nickel(II) derived from a Schiff base ligand. Eur. J. Inorg. Chem. 2009, 23, 3458-3466. [CrossRef]

18. Mukherjee, P.; Drew, M.G.B.; Gómez-García, C.J.; Ghosh, A. The crucial role of polyatomic anions in molecular architecture: Structural and magnetic versatility of five Nickel(II) complexes derived from A N,N,O-Donor Schiff base ligand. Inorg. Chem. 2009, 48, 5848-5860. [CrossRef]

19. Bonadio, F.; Senna, M.-C.; Ensling, J.; Sieber, A.; Neels, A.; Stoeckli-Evans, H.; Decurtins, S. Cyano-bridged structures based on $\left[\mathrm{Mn}^{\mathrm{II}}\left(\mathrm{N}_{3} \mathrm{O}_{2}-\text { Macrocycle }\right)\right]^{2+}$ : A synthetic, structural, and magnetic study. Inorg. Chem. 2005, 44, 969-978. [CrossRef]

20. Pioquinto-Mendoza, J.R.; Rosas-Ortiz, J.A.; Reyes-Martínez, R.; Conelly-Espinosa, P.; Toscano, R.A.; Germán-Acacio, J.M.; Avila-Sorrosa, A.; Baldovino-Pantaleón, O.; Morales-Morales, D. Synthesis, characterization and molecular structures of $\mathrm{Ni}(\mathrm{II})$ complexes derived from Schiff base pyridylimine ligands. Inorg. Chim. Acta 2015, 438, 146-152. [CrossRef]

21. Pioquinto-Mendoza, J.R.; Conelly-Espinosa, P.; Reyes-Martínez, R.; Toscano, R.A.; Germán-Acacio, J.M.; Avila-Sorrosa, A.; Baldovino-Pantaleón, O.; Morales-Morales, D. A simple and facile to prepare Pd(II) complex containing the pyridyl imine ligand $\left[\mathrm{C}_{5} \mathrm{H}_{4} \mathrm{~N}-2-\mathrm{CH}_{3} \mathrm{C}=\mathrm{N}-\left(\mathrm{CH}_{2}\right)_{3} \mathrm{NH}_{2}\right]$. Structural characterization and catalytic evaluation in Suzuki-Miyaura C-C couplings. J. Organomet. Chem. 2015, 797, 153-158. [CrossRef]

22. Williams, A.F. A structural analysis of $\left\{\mathrm{M}_{4} \mathrm{O}_{4}\right\}$ cubanes where $\mathrm{M}=\mathrm{Mn}$ and Fe. Dalton Trans. 2008, 6, 818-821. [CrossRef]

23. Isele, K.; Gigon, F.; Williams, A.F.; Bernardinelli, G.; Franz, P.; Decurtins, S. Synthesis, structure and properties of $\left\{\mathrm{M}_{4} \mathrm{O}_{4}\right\}$ cubanes containing nickel(ii) and cobalt(ii). Dalton Trans. 2007, 3, 332-341. [CrossRef] [PubMed]

24. Milios, C.J.; Prescimone, A.; Mishra, A.; Parsons, S.; Wernsdorfer, W.; Christou, G.; Perlepes, S.P.; Brechin, E.K. A rare ferromagnetic manganese(iii) 'cube'. Chem. Commun. 2007, 2, 153-155. [CrossRef] 
25. Aronica, C.; Chumakov, Y.; Jeanneau, E.; Luneau, D.; Neugebauer, P.; Barra, A.-L.; Gillon, B.; Goujon, A.; Cousson, A.; Tercero, J.; et al. Structure, magnetic properties, polarized neutron diffraction, and theoretical study of a Copper(II) Cubane. Chem. Eur. J. 2008, 14, 9540-9548. [CrossRef] [PubMed]

26. Qin, X.; Ding, S.; Xu, X.; Wang, R.; Song, Y.; Wang, Y.; Du, C.-f.; Liu, Z.-1. Synthesis, structure and magnetic properties of a series of cubane-like clusters derived from Schiff base ligands. Polyhedron 2014, 83, 36-43. [CrossRef]

27. Isele, K.; Franz, P.; Ambrus, C.; Bernardinelli, G.; Decurtins, S.; Williams, A.F. Self-assembly and interconversion of tetranuclear Copper(II) complexes. Inorg. Chem. 2005, 44, 3896-3906. [CrossRef]

28. Papaefstathiou, G.S.; Escuer, A.; Mautner, F.A.; Raptopoulou, C.; Terzis, A.; Perlepes, S.P.; Vicente, R. Use of the Di-2-pyridyl Ketone/Acetate/Dicyanamide "Blend" in Manganese(II), Cobalt(II) and Nickel(II) Chemistry: Neutral Cubane Complexes. Eur. J. Inorg. Chem. 2005, 5, 879-893. [CrossRef]

29. Kobayashi, F.; Ohtani, R.; Teraoka, S.; Kosaka, W.; Miyasaka, H.; Zhang, Y.; Lindoy, L.F.; Hayami, S.; Nakamura, M. Syntheses, structures and magnetic properties of tetranuclear cubane-type and heptanuclear wheel-type nickel(ii) complexes with 3-methoxysalicylic acid derivatives. Dalton Trans. 2017, 46, 8555-8561. [CrossRef] [PubMed]

30. Shiga, T.; Oshio, H. Molecular cubes with high-spin ground states. Sci. Technol. Adv. Mater 2005, 6, 565-570. [CrossRef]

31. Sartorel, A.; Bonchio, M.; Campagna, S.; Scandola, F. Tetrametallic molecular catalysts for photochemical water oxidation. Chem. Soc. Rev. 2013, 4, 2262-2280. [CrossRef]

32. Song, F.; Al-Ameed, K.; Schilling, M.; Fox, T.; Luber, S.; Patzke, G.R. Mechanistically Driven Control over Cubane Oxo Cluster Catalysts. J. Am. Chem. Soc. 2019, 141, 8846-8857. [CrossRef]

33. Li, J.; Zhou, Q.; Zhong, C.; Li, S.; Shen, Z.; Pu, J.; Liu, J.; Zhou, Y.; Zhang, H.; Ma, H. $(\mathrm{Co} / \mathrm{Fe})_{4} \mathrm{O}_{4}$ cubane-containing nanorings fabricated by phosphorylating cobalt ferrite for highly efficient oxygen evolution reaction. ACS Catal. 2019, 9, 3878-3887. [CrossRef]

34. Wu, Y.-P.; Tian, J.-W.; Liu, S.; Li, B.; Zhao, J.; Ma, L.-F.; Li, D.-S.; Lan, Y.-Q.; Bu, X. Bi-Microporous metal-organic frameworks with cubane $\left[\mathrm{M}_{4}(\mathrm{OH})_{4}\right](\mathrm{M}=\mathrm{Ni}, \mathrm{Co})$ clusters and pore-space partition for electrocatalytic methanol oxidation reaction. Angew. Chem. Int. Ed. 2019, 58, 12185-12189. [CrossRef] [PubMed]

35. Yang, E.-C.; Wernsdorfer, W.; Zakharov, L.N.; Karaki, Y.; Yamaguchi, A.; Isidro, R.M.; Lu, G.-D.; Wilson, S.A.; Rheingold, A.L.; Ishimoto, H.; et al. Fast magnetization tunneling in Tetranickel(II) single-molecule magnets. Inorg. Chem. 2006, 45, 529-546. [CrossRef] [PubMed]

36. Iasco, O.; Chumakov, Y.; Guégan, F.; Gillon, B.; Lenertz, M.; Bataille, A.; Jacquot, J.-F.; Luneau, D. Mapping the magnetic anisotropy inside a Ni4 cubane spin cluster using polarized neutron diffraction. Magnetochemistry 2017, 3, 25. [CrossRef]

37. Ponomaryov, A.N.; Kim, N.; Hwang, J.; Nojiri, H.; van Tol, J.; Ozarowski, A.; Park, J.; Jang, Z.; Suh, B.; Yoon, S.; et al. Structural tailoring effects on the magnetic behavior of symmetric and asymmetric cubane-type $\mathrm{Ni}$ complexes. Chem. Asian J. 2013, 8, 1152-1159. [CrossRef]

38. Rudbari, H.A.; Lloret, F.; Khorshidifard, M.; Bruno, G.; Julve, M. Effects of electron donating/withdrawing groups in the 5-substituted-2-hydroxybenzaldehyde on the synthesis of neutral cubanes with a Ni${ }_{4} \mathrm{O}_{4}$ core: Synthesis, crystal structures and magnetic properties. RSC Adv. 2016, 6, 7189-7194. [CrossRef]

39. Petit, S.; Neugebauer, P.; Pilet, G.; Chastanet, G.; Barra, A.-L.; Antunes, A.B.; Wernsdorfer, W.; Luneau, D. Condensation of a nickel tetranuclear cubane into a heptanuclear single-molecule magnet. Inorg. Chem. 2012, 51, 6645-6654. [CrossRef] [PubMed]

40. Mukherjee, S.; Weyhermüller, T.; Bothe, E.; Wieghardt, K.; Chaudhuri, P. Single-atom o-bridged urea in a Dinickel(II) complex together with $\mathrm{Ni}^{\mathrm{II}}{ }_{4}, \mathrm{Cu}^{\mathrm{II}}{ }_{2}$ and $\mathrm{Cu}^{\mathrm{II}}{ }_{4}$ complexes of a pentadentate phenol-containing Schiff base with $(\mathrm{O}, \mathrm{N}, \mathrm{O}, \mathrm{N}, \mathrm{O})$-Donor atoms. Eur. J. Inorg. Chem. 2003, 5, 863-875. [CrossRef]

41. Halcrow, M.A.; Sun, J.-S.; Huffman, J.C.; Christou, G. Structural and magnetic properties of $\left[\mathrm{Ni}_{4}\left(\mu_{3}-\mathrm{OMe}\right)_{4}(\mathrm{dbm})_{4}(\mathrm{MeOH})_{4}\right]$ and $\left[\mathrm{Ni}_{4}\left(\eta^{1}, \mu_{3}-\mathrm{N}_{3}\right)_{4}(\mathrm{dbm})_{4}(\mathrm{EtOH})_{4}\right]$. Magnetostructural correlations for $\left[\mathrm{Ni}_{4} \mathrm{X}_{4}\right]^{4+}$ cubane complexes. Inorg. Chem. 1995, 34, 4167-4177. [CrossRef]

42. Das, A.; Klinke, F.J.; Demeshko, S.; Meyer, S.; Dechert, S.; Meyer, F. Reversible solvatomagnetic effect in novel tetranuclear cubane-type $\mathrm{Ni} 4$ complexes and magnetostructural correlations for the $\left[\mathrm{Ni}_{4}\left(\mu_{3}-\mathrm{O}\right)_{4}\right]$ core. Inorg. Chem. 2012, 51, 8141-8149. [CrossRef] 
43. Karmakar, S.; Khanra, S. Polynuclear coordination compounds: A magnetostructural study of ferromagnetically coupled $\mathrm{Ni}_{4} \mathrm{O}_{4}$ cubane core motif. CrystEngComm 2014, 16, 2371-2383. [CrossRef]

44. Syamal, A.; Kumar, D. New oxozirconium(IV) complexes with the Schiff bases derived from salicylaldehyde or substituted salicylaldehydes and o-aminobenzyl alcohol. Indian J. Chem. Sect. A 1980, 19A, 1018-1020.

45. Syamal, A.; Singhal, O.P. New dioxouranium(VI) complexes with tridentate dibasic Schiff bases containing ONO donor sets. Transit. Met. Chem. 1979, 4, 179-182. [CrossRef]

46. Bruker. SMART (Version 5.628) and SAINT (Version 6.02); Bruker AXS Inc.: Madison, WI, USA, 1998.

47. Sheldrick, G.M. SADABS. Program for Empirical Absorption Correction of Area Detector; University of Göttingen: Göttingen, Germany, 1996.

48. Sheldrick, G. A short history of SHELX. Acta Crystallogr. A 2008, 64, 112-122. [CrossRef]

49. Ray, A.; Sadhukhan, D.; Rosair, G.M.; Gómez-García, C.J.; Mitra, S. An unprecedented Cu ${ }^{\text {II }-S c h i f f ~ b a s e ~}$ complex existing as two different trinuclear units with strong antiferromagnetic couplings. Polyhedron 2009, 28, 3542-3550. [CrossRef]

50. Marinescu, G.; Madalan, A.M.; Shova, S.; Andruh, M. Tetranuclear Zn(II) complexes with compartmental and dicyanamido ligands: Synthesis, structure, and luminescent properties. J. Coord. Chem. 2012, 65, 1539-1547. [CrossRef]

51. Majumder, A.; Rosair, G.M.; Mallick, A.; Chattopadhyay, N.; Mitra, S. Synthesis, structures and fluorescence of nickel, zinc and cadmium complexes with the N,N,O-tridentate Schiff base N-2-pyridylmethylidene-2-hydroxy-phenylamine. Polyhedron 2006, 25, 1753-1762. [CrossRef]

52. El-Sherif, A.A.; Fetoh, A.; Abdulhamed, Y.K.; Abu El-Reash, G.M. Synthesis, structural characterization, DFT studies and biological activity of $\mathrm{Cu}(\mathrm{II})$ and $\mathrm{Ni}(\mathrm{II})$ complexes of novel hydrazone. Inorg. Chim. Acta 2018, 480, 1-15. [CrossRef]

53. Sadhukhan, D.; Ray, A.; Pilet, G.; Rizzoli, C.; Rosair, G.M.; Gómez-García, C.J.; Signorella, S.; Bellú, S.; Mitra, S. Weak interactions modulating the dimensionality in supramolecular architectures in three new Nickel(II)-hydrazone complexes, magnetostructural correlation, and catalytic potential for epoxidation of alkenes under phase transfer conditions. Inorg. Chem. 2011, 50, 8326-8339. [CrossRef]

54. Bessy Raj, B.N.; Prathapachandra Kurup, M.R.; Suresh, E. Synthesis, spectral characterization and crystal structure of N-2-hydroxy-4-methoxybenzaldehyde- $\mathrm{N}^{\prime}$-4-nitrobenzoyl hydrazone and its square planar $\mathrm{Cu}$ (II) complex. Spectrochim. Acta A 2008, 71, 1253-1260. [CrossRef]

55. Zangrando, E.; Islam, M.T.; Islam, M.A.-A.A.A.; Sheikh, M.C.; Tarafder, M.T.H.; Miyatake, R.; Zahan, R.; Hossain, M.A. Synthesis, characterization and bio-activity of nickel(II) and copper(II) complexes of a bidentate NS Schiff base of S-benzyl dithiocarbazate. Inorg. Chim. Acta 2015, 427, 278-284. [CrossRef]

56. Escuer, A.; Font-Bardıa, M.; Kumar, S.B.; Solans, X.; Vicente, R. Two new nickel(II) cubane compounds derived from pyridine-2-methoxide (Pym): $\left\{\mathrm{Ni}_{4}(\mathrm{Pym})_{4} \mathrm{Cl}_{4}\left(\mathrm{CH}_{3} \mathrm{OH}\right)_{4}\right\}$ and $\left\{\mathrm{Ni}_{4}(\mathrm{Pym})_{4}\left(\mathrm{~N}_{3}\right)_{4}\left(\mathrm{CH}_{3} \mathrm{OH}\right)_{4}\right\}$. Crystal structures and magnetic properties. Polyhedron 1999, 18, 909-914. [CrossRef]

57. Yoshitake, M.; Nishihashi, M.; Ogata, Y.; Yoneda, K.; Yamada, Y.; Sakiyama, H.; Mishima, A.; Ohba, M.; Koikawa, M. Syntheses, structures, and magnetic properties of cubane-based cobalt and nickel complexes with ONO-tridentate ligands. Polyhedron 2017, 136, 136-142. [CrossRef]

58. Lu, Z.; Fan, T.; Guo, W.; Lu, J.; Fan, C. Synthesis, structure and magnetism of three cubane Cu(II) and Ni(II) complexes based on flexible Schiff-base ligands. Inorg. Chim. Acta 2013, 400, 191-196. [CrossRef]

59. Wikstrom, J.P.; Nazarenko, A.Y.; Reiff, W.M.; Rybak-Akimova, E.V. Synthesis and characterization of tetrakis( $\mu$-hydroxo)tetrakis(2,2'-dipicolylamine)tetranickel perchlorate, a nickel-hydroxy cubane complex. Inorg. Chim. Acta 2007, 360, 3733-3740. [CrossRef]

60. Wang, J.; Feng, C.; Ge, C.M.; Zhang, S.; Hai, H. Two new cubane-type tetranuclear compounds of Copper(II), Nickel(II) derived from reduced schiff base ligand: Syntheses, structures and magnetic properties. J. Clust. Sci. 2016, 27, 2001-2011. [CrossRef]

61. Gungor, E.; Kara, H. Ferromagnetic coupling in two tetranuclear Ni(II) complexes with cubane-like $\mathrm{Ni}_{4}\left(\mu_{3}-\mathrm{O}\right)_{4}$ core: Structure, spectroscopic and luminescence properties. J. Mol. Struct. 2020, 1208, 127859. [CrossRef] 
62. Jana, M.S.; Priego, J.L.; Jiménez-Aparicio, R.; Mondal, T.K. Novel tetranuclear Ni(II) Schiff base complex containing $\mathrm{Ni}_{4} \mathrm{O}_{4}$ cubane core: Synthesis, X-ray structure, spectra and magnetic properties. Spectrochim. Acta A 2014, 133, 714-719. [CrossRef]

63. Torić, F.; Pavlović, G.; Pajić, D.; Cindrić, M.; Zadro, K. Tetranuclear $\mathrm{Ni}_{4}$ cubane complexes with high $\chi \mathrm{T}$ maxima: Magneto-structural analysis. CrystEngComm 2018, 20, 3917-3927. [CrossRef]

(C) 2020 by the authors. Licensee MDPI, Basel, Switzerland. This article is an open access article distributed under the terms and conditions of the Creative Commons Attribution (CC BY) license (http://creativecommons.org/licenses/by/4.0/). 